Reprod. Nutr. Dévelop., 1986, 26 (2 B), 683-690.

\title{
Relationship between nutrient intake, growth and body composition of the nursing foal
}

\author{
M. DOREAU, Sylviane BOULOT, W. MARTIN-ROSSET (*), J. ROBELIN $\left({ }^{* *}\right)$ \\ with the technical assistance of $\mathrm{H}$. DUBROEUCO $\left(^{*}\right)$ and Renée LEFAIVRE \\ Laboratoire de la Lactation. \\ (*) Unité Elevage et Alimentation du Cheval. \\ (*) Laboratoire de la Production de Viande, \\ I.N.R.A. Theix, 63122 Ceyrat, France.
}

Summary. The milk and nutrient intakes of 21 nursing foals of heavy breeds (adult weight : $800 \mathrm{~kg}$ ) were determined at 1,4 and 8 weeks of age. Lactose intake increased $(\mathrm{P}<0.01)$ from $1300 \mathrm{~g} /$ day at 1 week of age to $1800 \mathrm{~g} / \mathrm{d}$ at 8 weeks; fat decreased $(\mathrm{P}<0.01)$ from $400 \mathrm{~g} / \mathrm{d}$ to $300 \mathrm{~g} / \mathrm{d}$ and protein did not vary $(600 \mathrm{~g} / \mathrm{d})$. Energy and nitrogen intakes did not depend on the source of energy in the mother's diet.

Milk, energy and nitrogen intakes were well related $(r=0.74$ to 0.81$)$ with foal growth between 1 and 4 weeks, but not between 4 and 8 weeks. The composition of weight gain showed a greater deposition of protein than of lipids until 8 weeks. Lipid and protein contents in empty body weight were 5.3 and $19.2 \%$, respectively, at 1 week and 9.0 and $19.9 \%$ at 8 weeks.

\section{Introduction.}

During the first months of postnatal life, the foal eats only a few solid feeds (Martin-Rosset, Doreau and Cloix, 1978). Almost all the nutrients needed to meet maintenance and growth requirements come from the mare's milk. Preliminary studies on a few animals (Doreau, Martin-Rosset and Dubroeucq, 1982) have shown a weak relationship between milk intake and foal growth. This relationship is stronger in other species such as cattle (Le Neindre, 1974) or rabbits (Lebas, 1969).

In the present trial, we took into consideration milk composition and analyzed relationships between milk, energy and nitrogen intakes on the one hand, and foal liveweight gain and lipid and protein retention in vivo on the other.

\section{Material and methods.}

Animals and experimental diets. - Twenty-one mare/foal pairs of heavy French breeds (Bretonne, Comtoise), weighing on an average $800 \mathrm{~kg}$ when adult, were studied during the first two months of nursing. In 1983 ten mares were divided 
into two groups. Five mares received a diet ad libitum containing $95 \%$ of tall fescue hay ( 2 nd cut) and $5 \%$ of a concentrate (93\% soybean meal) (group 1a) ; the other 5 received a diet containing $50 \%$ of the same hay and $50 \%$ of a concentrate $(83 \%$ barley and $12 \%$ soybean meal) (group 1b). These diets provided sufficient amounts of nitrogen but differed as to the estimated amount of glucose in the end-products of digestion. During the same period in 1984, 11 mares received a diet containing $85 \%$ of natural grassland hay (1st cut) and $15 \%$ of a concentrate (50\% barley and $45 \%$ soybean meal) (group 2 ). The main results on milk production and composition will be published elsewhere.

\section{Measurements}

Foal intake of milk and nutrients. - Milk intake was determined by the dilution of deuterium oxide, as a marker of foal body water, according to Doreau and Dussap (1980) at 1, 4 and 8 weeks of lactation. A milk sample was taken during a milking representative of sucking as described by Doreau et al. (1986). Milk composition was determined by Gerber for fat, Kjeldahl for nitrogen, infrared spectrophotometry for lactose, atomic absorption spectrophotometry for calcium and colorimetry for phosphorus. Gross energy was measured by calorimetry (group 2) or estimated (groups $1 \mathrm{a}$ and $1 \mathrm{~b}$ ) by multiple regression from 27 samples of group 2, according to the following formula :

$$
\mathrm{GE}=8.97 \mathrm{~F}+5.25 \mathrm{~N}+4.10 \mathrm{~L} \quad\left(\mathrm{r}^{2}=0.995 ; \mathrm{Syx}=6.0\right)
$$

where $G E$ is milk gross energy in $\mathrm{kcal} / \mathrm{kg}$ and $F, N$ and $L$ are milk fat, nitrogen $(\mathrm{N} \times 6.38)$ and lactose in $\mathrm{g} / \mathrm{kg}$, respectively.

Daily mean intakes of energy and nitrogen between weeks 1 and 4 (period 1) and between weeks 4 and 8 (period 2) were calculated by the arithmetical mean of the intake for each of the weeks limiting these periods.

Foal growth and body composition. - Foal liveweight was determined at 1 , 4 and 8 weeks by double weighing at fixed times. Body composition (lipid, protein) was estimated from the water content of empty body weight, as in other species. It was assumed that, as in growing cattle (Robelin, 1982), body water volume was $3 \%$ lower than deuterium oxide dilution space. Empty body weight and empty body water (EBWAT) were estimated assuming that digestive content was $3 \%$ of the liveweight at 1 and 4 weeks and $4 \%$ at 8 weeks (as in calves) and contained $88 \%$ water. Lipid weight, calculated by the difference between empty body weight and the fat-free mass (FFM), was obtained with the equation : FFM $=1.161$ EBWAT ${ }^{1.026}$, established from slaughter data on light breed foals at birth (Meyer and Ahlswede, 1976) and at 4 months (Schryver et al., 1974), taking into consideration the differences in maturity between heavy and light breeds for a same body weight. It was assumed that the body water/fat-free mass ratio was the same for the two types at the same maturity, Protein weight was estimated as $79 \%$ of fat-free dry matter from bibliographical data on 4-month old foals.

From these estimates of body composition at 1,4 and 8 weeks, we calculated the amount of lipids and proteins retained during periods 1 (weeks 1 to 4 ) and 
2 (weeks 4 to 8 ). The energy retained was calculated assuming a gross energy value of $9.31 \mathrm{kcal} / \mathrm{g}$ for lipids and of $5.38 \mathrm{kcal} / \mathrm{g}$ for proteins (Robb et al., 1972).

\section{Results.}

Foal nutrient intake. - Nutrient intake (fig. 1) was 1000 to $2000 \mathrm{~g}$ of lactose, 500 to $700 \mathrm{~g}$ of protein and 200 to $500 \mathrm{~g}$ of fat daily. These data were submitted to variance analysis with two main factors (group, lactation stage), a hierarchical effect (animal) and a group/stage interaction. Lactose intake increased sharply $(P<0.01)$ between 1 and 8 weeks while gross energy increased only between 1 and 4 weeks $(P<0.01)$. Fat decreased $(P<0.01)$ and crude protein was fed in rather constant quantities. The differences between groups were significant $(P<0.05)$ for lactose, fat and gross energy intakes but not for protein intake. The daily intake of calcium and phosphorus did not differ between groups or stages; the mean values for each stage were 28.7, 29.8 and $26.7 \mathrm{~g}$ of $\mathrm{Ca}$ and $11.2,11.7$ and $10.6 \mathrm{~g}$ of $\mathrm{P}$ at weeks 1,4 and 8 , respectively. These different results must be related to a slight variation in daily milk intake between stages and groups (Doreau et al., in progress); at weeks 1, 4 and 8 they were respectively $18.9 \pm 1.8,23.4 \pm 5.3$ and $26.0 \pm 7.5 \mathrm{~kg}$ for group 1a; $21.0 \pm 2.0,26.6 \pm 2.2$ and $23.0 \pm 2.5 \mathrm{~kg}$ for group $1 \mathrm{~b} ; 21.7 \pm 1.1,23.8 \pm 1.1$ and $24.6 \pm 1.0 \mathrm{~kg}$ for group 2. Nutrient intake per $\mathrm{kg}$ of metabolic weight decreased regularly ; at 1,4 and 8 weeks the means were $50.5,41.7$ and $35.5 \mathrm{~g}$ of lactose ; 20.6, 14.4 and $11.5 \mathrm{~g}$ of protein ; $15.4,9.8$ and $6.0 \mathrm{~g}$ of fat and 453,339 and $250 \mathrm{kcal}$ of gross energy.
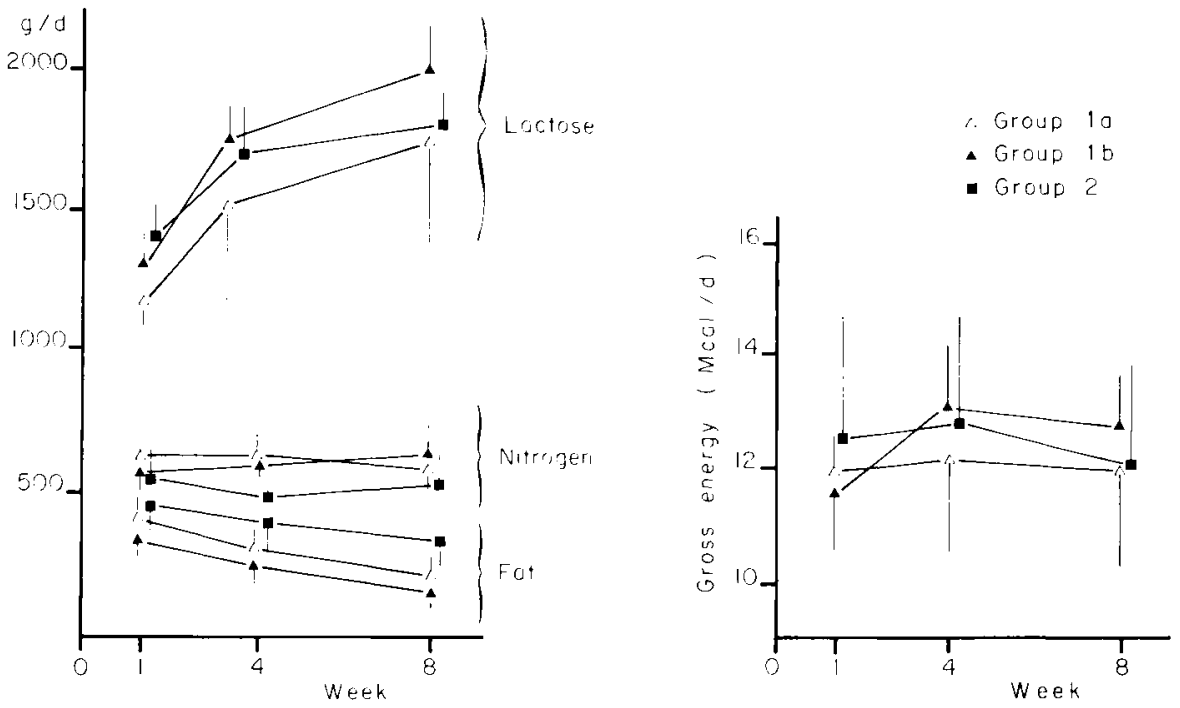

FIG. 1. - Quantity of foal nutrient intake (mean and standard deviation). 
Relationship between milk or nutrient intake and foal growth. - The amounts of milk, gross energy and protein intake per $\mathrm{kg}$ of foal liveweight gain were $10.6 \pm 0.9 \mathrm{~kg}, 5.8 \pm 0.5 \mathrm{Mcal}$ and $258 \pm 27 \mathrm{~g}$, respectively, in period 1 and $13.7 \pm 1.7 \mathrm{~kg}, 6.5 \pm 0.7 \mathrm{Mcal}$ and $292 \pm 34 \mathrm{~g}$ in period 2 .

The linear correlation between milk intake and foal liveweight gain (fig. 2) was better in period $1(r=0.81 ; n=19 ; P<0.01)$ than in period $2(r=0.74$; $\mathrm{n}=18 ; \mathrm{P}<0.01$ ). Liveweight gain was no longer related with gross energy intake $(r=0.78$ in period $1 ; r=0.68$ in period 2$)$ or protein intake $(r=0.74$ and 0.61 respectively). These relationships were all significant $(P<0.01)$. The relationship between liveweight gain and milk or gross energy intake did not vary according to group. However, the relationship differed between groups $1 \mathrm{a}$ and $1 \mathrm{~b}$ on one hand, and group 2 on the other, as to liveweight gain and nitrogen intake : the respective correlation coefficients were $0.87(\mathrm{n}=10 ; \mathrm{P}<0.01$ ) and 0.84 ( $n=9 ; P<0.01$ ). There was no correlation between liveweight gain and the milk energy/protein ratio.

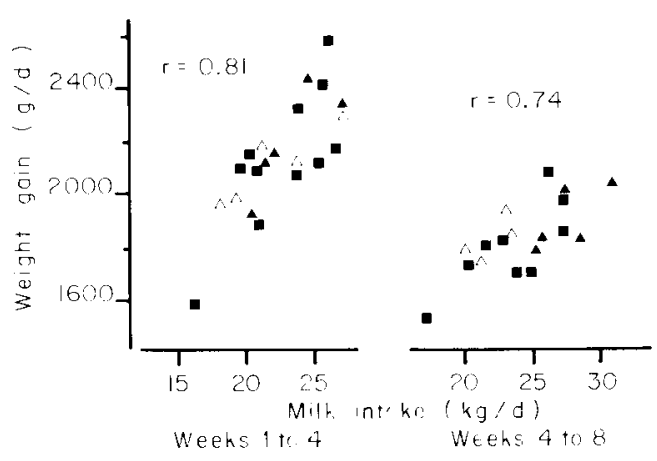

FIG. 2. - Relationship between foal milk intake and foal liveweight gain (mean and standard deviation). $\triangle$ Group 1a ; $\mathbf{A}$ Group 1b; $\mathbf{0}$ Group 2.

Foal body composition and nutrient retention. - The proportion of EBWAT in the empty body weight of 21 foals was $70.6 \pm 1.8,69.1 \pm 1.9$ and $66.2 \pm 1.7 \%$ at 1,4 and 8 weeks, respectively. The equations of marker dilution used for this measurement were all adjusted with a correlation coefficient higher than 0.991. Body composition was estimated in 14 foals (table 1 ) ; we discarded 7 of these results, in which one of the three mean EBWAT/empty body weight ratios was 1.5 times higher than the standard deviation.

The percentage of lipid in empty body increased greatly between 1 and 8 weeks, whereas the percentage of protein remained rather constant. However, during this period, protein deposition $(19.3 \mathrm{~kg})$ was higher than lipid retention $(11.3 \mathrm{~kg})$. So, in period 1, the foals retained, per day, $184 \pm 101 \mathrm{~g}$ of fat, $446 \pm 60 \mathrm{~g}$ of protein and $4.1 \pm 0.9$ Mcal of gross energy. In period 2, daily retention was $265 \pm 80 \mathrm{~g}, 342 \pm 39 \mathrm{~g}$ and $4.3 \pm 0.8$ Mcal, respectively. The ratio of protein and lipid retained varied from 2.4 in period 1 to 1.3 in period 2 . 
Foal body composition (mean and standard deviation).

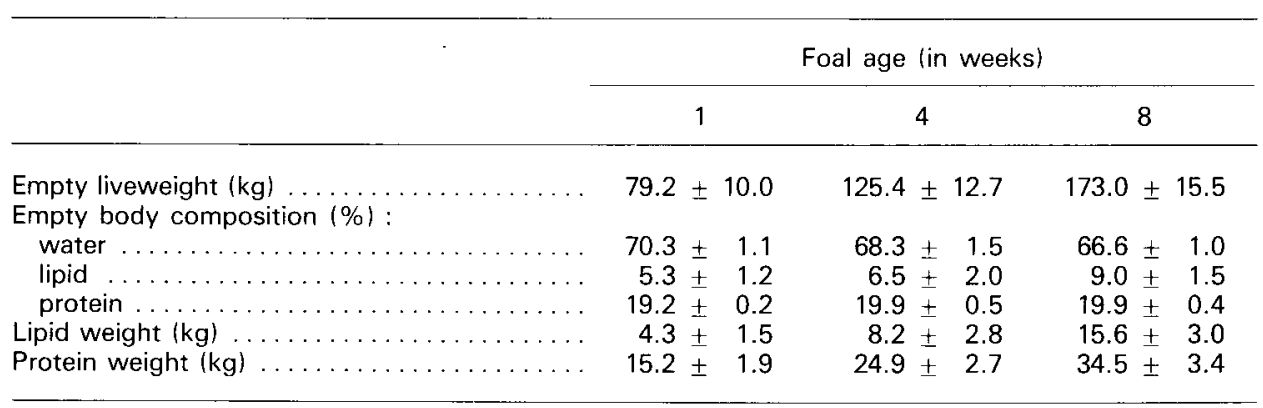

\section{Discussion.}

Foal nutrient intake. - The intake levels of the different nutrients absorbed were independent of the mare's diet. As the milk composition is modified, the foal, as the calf (Le Neindre, 1974), probably adjusts its milk intake to fit nutrient requirements. The milk production of the mare fed ad libitum did not seem to limit foal growth. This hypothesis is supported by a low variation in nutrient intake between birth and 2 months as well as in requirements calculated from the theoretical growth curve (Martin-Rosset, Doreau and Espinasse, 1986).

Milk intake per $\mathrm{kg}$ of liveweight gain between 10 and $14 \mathrm{~kg}$ confirms results obtained by ourselves (Doreau, Martin-Rosset and Dubroeucq, 1982) or by Bouwman and Van der Schee (1978) and Oftedal, Hintz and Schryver (1983) with light breeds.

Relationship between nutrient intake and foal growth. - The relationship between foal liveweight gain and milk intake was closer in this trial than in a previous work (Doreau, Martin-Rosset and Dubroeucq, 1982), probably because there were more data and the calculation of liveweight gain over a longer period was more accurate. However, this relationship is weaker than that obtained by Salmon-Legagneur and Aumaitre (1962) in piglets or by Lebas (1969) in young rabbits. Perhaps these differences are related to methodological problems or feeding conditions since other authors studying piglets obtained a correlation of 0.58 (Lewis, Speer and Haught, 1978). These species differences might be due to the proportion of maintenance in the total requirements, which are higher and more variable in foals than in piglets or young rabbits.

The strength of the relationship decreases with foal age, probably because of the greater proportion of maintenance requirement and because of a possible intake of low amounts of forage after one month of age. It is surprising that this relationship is not higher when liveweight gain is related to energy or nitrogen intake. It may be that two milkings are not enough to precisely determine mean milk composition over a 3 or 4 -week period.

In period 1, the relationship between protein intake and liveweight gain was very close within the same year of measurement. This could indicate that the 
nitrogen supply, more than the energy supply, limited foal growth during this period, as suggested by the high protein retention/protein intake ratio. Such an observation was made in weaned foals eating a lysine-deficient diet (Breuer and Golden, 1971) and in reared lambs given an low-protein diet (Norton, Jagusch and Walker, 1970). These results are not found in nursing offspring; milk generally equilibrates the nutrients, allowing optimal growth. Meadows et al. (1979) observed that a protein deficiency in the mare's diet caused a decrease in foal growth, but it is possible that the milk protein percentage does not vary when milk yield decreases, as in cows (Rémond, 1985), leading to limited supplies of energy and nitrogen at the same time.

Foal body composition. - The percentage of water in the foal body was close to that previously obtained by the same method (Doreau, Martin-Rosset and Agabriel, 1983) and consistent with most published data, particularly those of Schryver et al. (1974) and Meyer and Ahlswede (1976) on slaughtered animals only; the in vivo values of Oftedal, Hintz and Schryver (1983) are considerably higher.

The calculated percentages of empty body lipid (nearly $6 \%$ at week 1 and $9 \%$ at 2 months) were higher than obtained in saddle breeds : $2.6 \%$ at birth (Meyer and Ahlswede, 1976) and $5.3 \%$ at 4 months (Schryver et al., 1974). Heavy breed horses probably have more fat at the same age than saddle horses (Julian et al., 1956). A methodological problem certainly remains to be solved, but it is difficult to evaluate the more reliable data. Estimated lipid percentages vary between 1.4 (Mendel, 1973) and $24 \%$ (Julian et al., 1956) of liveweight in adult horses. This variation is comparable to that observed in ovines and cattle (see review of Robelin and Thériez, 1981). An intermediate value of $10 \%$ has been estimated for heavy breed foals at 6 months by Agabriel, Martin-Rosset and Robelin (1984).

Protein deposition is very high in the first months after birth. It is higher than lipid deposition at 2 months, at which time, this is not true in ruminants (Robelin and Thériez, 1981) or in swine (Whittemore, Aumaitre and Williams, 1978) at the same proportion of adult weight. This can be related to the low percentage of adipose tissue in horses as compared to that of other species (Martin-Rosset et al., 1983).

\section{Conclusion.}

Nursing foals have a very high growth rate, permitting body weight to double between birth and 2 months. This is due to a high nutrient intake. The nature of the carbohydrates in the mare's diet, when fed ad libitum, does not modify foal intake of energy or protein. However, different problems that remain to be studied are : the putative role of the protein supply in the mare's diet as a limiting factor of foal growth and its consequences on the composition of foal weight gain : more generally, the conditions in which the mare's milk yield limits foal growth. 
Résumé. Relation entre les nutriments ingérés et la croissance chez le poulain allaité.

La consommation de lait et de nutriments par des poulains allaités de race lourde (poids adulte : $800 \mathrm{~kg}$ ) a été déterminée à 1,4 et 8 semaines sur 21 poulains.

La consommation de lactose s'est accrue $(P<0,01)$ de $1300 \mathrm{~g} / \mathrm{j}$ à 1 semaine à $1800 \mathrm{~g} / \mathrm{j}$ à 8 semaines, la consommation de matières grasses a diminué $(\mathrm{P}<0,01)$ de 400 à $300 \mathrm{~g} / \mathrm{j}$ et celle de protéines n'a pas varié $(600 \mathrm{~g} / \mathrm{j})$.

Les quantités d'énergie et d'azote consommées n'ont pas dépendu de la nature des nutriments du régime de la mère.

Les consommations de lait, d'énergie et d'azote ont été bien reliées $(r=0,74$ à 0,81$)$ à la croissance du poulain entre 1 et 4 semaines, et moins bien entre 4 et 8 semaines. La composition du gain de poids a montré un dépôt de protéines plus important que le dépôt de lipides jusqu'à 8 semaines. Les teneurs en lipides et protéines du poids vif vide étaient respectivement de 5,3 et $19,2 \%$ à 1 semaine, 9,0 et $19,9 \%$ à 8 semaines.

\section{References}

AGABRIEL J., MARTIN-ROSSET W., ROBELIN J., 1984. Croissance et besoins du poulain. In R. JARRIGE, W. MARTIN-ROSSET, Le Cheval. Reproduction, sélection, alimentation, exploitation, I.N.R.A., Paris, 371-384.

BOUWMAN H., VAN DER SCHEE W., 1978. Composition and production of milk from dutch warmblooded saddle horse mares. Z. Tierphysiol. Tierernährg. Futtermittelk., 40, 39-53.

BREUER L. H., GOLDEN D. L., 1971. Lysine requirements of the immature equine. J. anim. Sci., 33, 227.

DOREAU M., DUSSAP G., 1980. Estimation de la production laitière de la jument allaitante par marquage de l'eau corporelle du poulain. Reprod. Nutr. Dévelop., 20, 1883-1892.

DOREAU M., MARTIN-ROSSET W., DUBROEUCQ H., 1982. Production laitière de la jument. Liaison avec la croissance du poulain. C. R. 8 e Journée d'Etude CEREOPA, Paris, 88-100.

DOREAU M., MARTIN-ROSSET W., AGABRIEL J., 1983. Estimation de la production laitière de la jument. Proc. 34th Meet. EAAP, Madrid, 888-889.

DOREAU M., BOULOT S., MARTIN-ROSSET W., DUBROEUCQ H., 1986. Milking lactating mares using oxytocin : volume and composition of milk. Reprod. Nutr. Dévelop., 26, 1-11.

JULIAN L. M., LAWRENCE J. H., BERLIN N. I., HYDE G. M., 1956. Blood volume, body water and body fat of the horse. J. appl. Physiol., 8, 651-653.

LEBAS F., 1969. Alimentation lactée et croissance pondérale du lapin avant sevrage. Ann. Zootech., 18, 197-208.

LE NEINDRE P., 1974. Production laitière de vaches allaitantes et liaison entre cette production et la croissance de leurs veaux. In L'exploitation des troupeaux de vaches allaitantes, I.N.R.A.ITEB, 212-230.

LEWIS A. J., SPEER V. C., HAUGHT D. G., 1978. Relationship between yield and composition of sows milk and weight gains of nursing pigs. J. anim. Sci, 47, 634-638.

MARTIN-ROSSET W., DOREAU M., CLOIX J., 1978. Etude des activités d'un troupeau de poulinières de trait et de leurs poulains au pâturage. Ann. Zootech., 27, 33-45.

MARTIN-ROSSET W., BOCCARD R., JUSSIAUX M., ROBELIN J., TRILLAUD-GEYL C., 1983. Croissance relative des différents tissus, organes et régions corporelles entre 12 et 30 mois chez le cheval de boucherie de différentes races lourdes. Ann. Zootech., 32, 153-174.

MARTIN-ROSSET W., DOREAU M., ESPINASSE J., 1986. Alimentation de la jument lourde allaitante. Evolution du poids vif des juments et croissance des poulains. Ann. Zootech. (sous presse).

MEAdOWS D. G., POTTER G. D., THOMAS W. B., HESBY J. H., ANDERSON J., 1979. Foal growth from mares fed supplemental soybean meal or urea. Proc. 6th Eq. Nutr. Physiol. Symp., College Stat, 14-16.

MENDEL V. E., 1973. Voluntary food intake and body composition in the young horse. Proc. 3rd Eq. Nutr. Physiol. Symp., Gainesville, 75-80.

MEYER H., AHLSWEDE L., 1976. Uber das intrauterine Wachstum und die Körperzusammensetzung von Fohlen sowie den Nährstoffbedarf tragender Stuten. Ubers. Tierernährg., 4, 263-292. 
NORTON B. W., JAGUSCH K. T., WALKER D. M., 1970. Body composition studies with the milk-fed lamb. III. The effect of the protein and energy intake on the composition of the liveweight gain. J. agric. Sci., Camb., 75, 287-292.

OFTEDAL O. T., HINTZ H. F., SCHRYVER H. F., 1983. Lactation in the horse : milk composition and intake by foals. J. Nutr., 113, 2196-2206.

RÉMOND B., 1985. Influence de l'alimentation sur la composition du lait de vache. 2. Taux protéique : facteurs généraux. Bull. Tech. CRZV Theix, I.N.R.A., 62, 53-67.

ROBB J., HARPER R. B., HINTZ H. F., REID J. T., LOWE J. E., SCHRYVER H. F., RHEE M. S. S., 1972. Chemical composition and energy value of the body, fatty acid composition of adipose tissue, and liver and kidney size in the horse. Anim. Prod., 14, 25-34.

ROBELIN J., 1982. Relation entre l'espace de diffusion de l'eau lourde mesurée in vivo et le volume hydrique corporel des bovins en croissance. Reprod. Nutr. Dévelop., 22, 65-73.

ROBELIN J., THÉRIEZ M., 1981. Fixation de protéines chez les ruminants : évolution en fonction du poids des animaux et variations selon la race, le sexe ou le niveau des apports alimentaires. Reprod. Nutr. Dévelop., 21, 335-353.

SALMON-LEGAGNEUR E., AUMAITRE A., 1962. Influence de la quantité de lait et de sa composition sur la croissance du porcelet sous la mère. Ann. Zootech., 11, 181-196.

SCHRYVER H. F., HINTZ H. F., LOWE J. E., HINTZ R. L., HARPER R. B., REID J. T., 1974. Mineral composition of the whole body, liver and bone of young horses. J. Nutr., 104, 126132.

WHITTEMORE C. T., AUMAITRE A., WILLIAMS J. H., 1978. Growth of body components in young weaned pigs. J. agric. Sci., Camb., 91, 681-692. 